\title{
Niat Adopsi dan Preferensi Konsumen terhadap Produk Baru Pupuk Mini Size untuk Petani Kecil
}

\author{
Venny Novinita Agustina Putri dan Janti Gunawan \\ Departemen Manajemen Bisnis, Institut Teknologi Sepuluh Nopember (ITS) \\ e-mail: jantigunawan2010@gmail.com
}

\begin{abstract}
Abstrak-Permasalahan yang dialami petani terkait pupuk nonorganik bersubsidi menjadi peluang bagi AMINA (pupuk nonorganik hasil samping produksi penyedap masakan PT Ajinomoto Indonesia) untuk memasuki pasar. AMINA selama ini dijual dalam skala besar (tangki) yang hanya bisa dikonsumsi oleh petani skala besar. Demi meningkatkan penjualan, PT Ajinomoto Indonesia hendak menyasar petani kecil dengan meluncurkan produk AMINA skala kecil yang disebut mini size AMINA. Sebagai produk baru, perusahaan melakukan uji coba pasar pada petani jagung dan bawang merah di Lamongan untuk mengetahui tingkat penerimaan mini size AMINA agar terhindar dari kegagalan pasar. Oleh karena itu, penelitian ini bertujuan untuk mengidentifikasi tingkat niat adopsi, faktor yang memengaruhi niat adopsi, dan preferensi atribut produk pada petani jagung dan bawang merah di Lamongan. Penelitian menggunakan metode kualitatif dengan pendekatan studi kasus kepada dua belas petani. Dari hasil penelitian diperoleh bahwa tingkat niat adopsi dari petani jagung dan bawang merah cukup besar, yaitu 7 dari 12 petani $(58 \%)$ menyatakan memiliki niat adopsi terhadap produk dengan skor kepuasan 8-10 yang diukur dari tampak fisik tanaman dan kemudahan penggunaan produk. Hasil analisis menunjukkan bahwa faktor relative advantage, compatibility, complexity, observability, dan trialability memengaruhi petani untuk berniat mengadopsi produk. Preferensi sebagian besar responden terkait atribut produk mini size AMINA antara lain harga dengan rentang Rp5.000-Rp6.000, volume 20 liter, tidak memiliki keterangan sertifikasi produk, dan tempat pembelian berjarak antara 2-3 kilometer dari lahan bertani.
\end{abstract}

Kata Kunci-Atribut produk, Niat adopsi, Petani kecil, Preferensi konsumen, Pupuk.

\section{PENDAHULUAN}

CEKTOR pertanian memiliki peran strategis dalam pembangunan perekonomian nasional dan hingga kini masih menjadi salah satu penyumbang terbesar PDB nasional. PDB sektor pertanian senantiasa mengalami pertumbuhan dalam 4 tahun terakhir [1]. Hal ini menunjukkan bahwa sektor pertanian memiliki tren perkembangan yang semakin baik, didukung dengan peningkatan hasil produksi pertanian dalam 4 tahun terakhir [2]. Hal ini tak lepas dari peran fungsi pupuk sebagai salah satu faktor input utama dalam produksi pertanian.

Konsumsi pupuk nasional hingga saat ini masih didominasi oleh pupuk non-organik [3]. Selain karena persepsi petani mengenai adanya tambahan zat kimia dalam pupuk nonorganik yang dapat meningkatkan produktivitas lebih cepat dibanding pupuk organik, namun juga karena adanya alokasi subsidi pemerintah. Subsidi pupuk dari pemerintah pada dasarnya ditujukan bagi petani kecil yang kepemilikan lahannya terbatas, sehingga dapat membantu petani kecil dalam mendapatkan pupuk dengan harga terjangkau.

Petani kecil yang selama ini telah bergantung dengan pupuk bersubsidi kini diresahkan dengan adanya keputusan pengurangan alokasi pupuk bersubsidi yang disampaikan oleh Kementrian Pertanian [4]. Namun, semakin dibatasinya volume pupuk subsidi justru dapat menjadi peluang bagi produsen pupuk non-organik lain untuk memasuki pasar sebagai produk subtitusi. Salah satunya adalah pupuk hasil samping industri penyedap masakan PT Ajinomoto Indonesia yang bermerek AMINA.

Pupuk AMINA selama ini hanya dijual dalam skala besar (tangki) yang hanya dapat dikonsumsi oleh petani berlahan luas, namun PT Ajinomoto Indonesia kini hendak menyasar petani kecil dengan kepemilikan lahan terbatas agar dapat mengoptimalkan penjualan. Dalam hal ini, PT Ajinomoto Indonesia hendak memasarkan pupuk AMINA skala kecil dikhususkan untuk petani kecil yang disebut mini size AMINA.

Pupuk mini size AMINA yang merupakan produk baru bagi petani kecil, tentu tak lepas dari risiko kegagalan pasar. Banyak produk baru yang mengalami kegagagalan, karena tidak dapat diterima oleh pasar. Oleh karena itu, penerimaan terhadap produk baru pupuk mini size AMINA perlu dianalisis untuk menilai apakah produk dapat diterima pasar atau tidak. Demi menghindari risiko kegagalan produk di pasar baru yang akan dituju, PT Ajinomoto Indonesia memutuskan untuk melakukan uji coba pasar (market testing) pada petani jagung dan bawang merah di Lamongan yang merupakan salah satu target pasarnya. Dengan demikian tingkat niat adopsi dan faktor-faktor yang memengaruhi niat adopsi pupuk mini size AMINA oleh petani kecil sebagai target pasar baru penting untuk diteliti.

Selain niat adopsi, preferensi konsumen perlu dianalisis untuk mengetahui atribut produk seperti apa yang dapat diterima konsumen sebagai produk subtitusi [5]. Melibatkan konsumen dalam proses pengembangan produk baru dalam 
tahap konsep awal atau market testing dapat meningkatkan tingkat kesuksesan produk baru [6]. Sebab, informasi terkait karakteristik preferensi konsumen tersebut selanjutnya dapat dijadikan pertimbangan bagi PT Ajinomoto Indonesia dalam menentukan strategi komersialisasi produk baru mini size AMINA agar nantinya produk dapat diterima dengan baik pada pasar yang baru.

\section{TINJAUAN PUSTAKA}

\section{A. Niat Adopsi}

Niat adopsi adalah motivasi atau dorongan yang memprediksi perilaku aktual individu, yang dalam penelitian A. Karahoca et. all (2017) berkaitan dalam memutuskan akan menggunakan suatu produk inovasi dalam kesehariannya, sehingga niat adopsi adalah motivasi atau dorongan untuk menggunakan produk inovasi. Terminologi adopsi dalam Diffusion of Innovation Theory yang digagas E. M. Rogers (2003) seperti dalam penelitian L. Warner, C et.all (2019), digunakan untuk mengukur tingkat penerimaan produk inovasi pada sistem sosial. Inovasi adalah suatu gagasan, praktik, atau benda yang dianggap baru oleh individu atau kelompok masyarakat.

Tingkat adopsi inovasi dipengaruhi oleh 5 faktor, diantaranya relative advantage, compatibility, complexity, observability, dan trialability [7]. Relative advantage adalah tingkat sejauh mana produk yang baru dianggap lebih baik daripada produk yang digantikannya. Compatibility adalah tingkat sejauh mana produk baru dianggap konsisten atau sesuai dengan nilai-nilai yang ada, pengalaman masa lalu dan kebutuhan konsumen potensial. Complexity adalah sejauh mana produk baru dianggap sulit untuk dipahami dan digunakan. Observability adalah tingkat sejauh mana hasil penerapan produk baru dapat dilihat oleh orang lain. Trialability adalah tingkat sejauh mana produk baru dapat dicoba sebelum diadopsi. Kelima faktor tersebut berpengaruh terhadap keputusan adopsi dari inovasi apapun[8]. Hipotesis penelitian mengenai faktor niat adopsi adalah:

1) H1. Relative advantage berpengaruh positif terhadap niat adopsi pupuk mini size AMINA

2) H2. Compatibility berpengaruh positif terhadap niat adopsi pupuk mini size AMINA

3) H3. Complexity berpengaruh negatif terhadap niat adopsi pupuk mini size AMINA

4) H4. Observability berpengaruh positif terhadap niat adopsi pupuk mini size AMINA

5) H5. Trialability berpengaruh positif terhadap niat adopsi pupuk mini size AMINA

\section{B. Preferensi Konsumen}

Preferensi konsumen dapat berarti pilihan atau sesuatu hal yang lebih disukai konsumen, yang dapat dikaitkan dengan atribut produk [5]. Preferensi konsumen adalah motivasi positif yang diekspreksikan dengan kesesuaian individu terhadap atribut produk, baik berkaitan dengan substansi material produk (bentuk, ukuran, cetakan, rasa, warna,
Tabel 1.

Niat adopsi responden

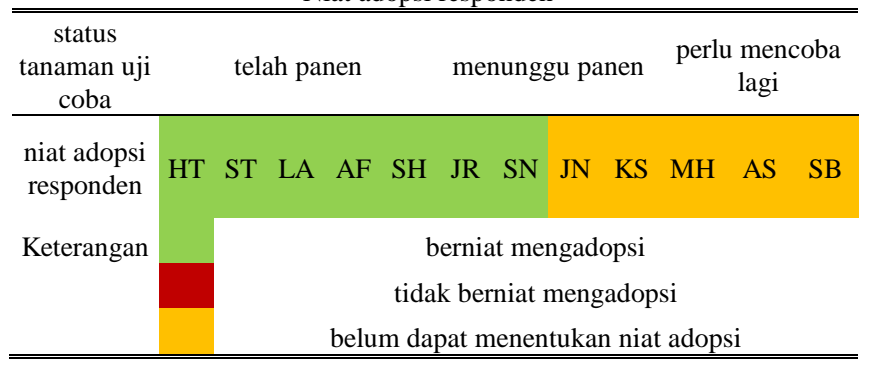

kemasan, dan lain sebagainya), maupun elemen lain seperti lebel, nama produk, instruksi penggunaan yang melekat pada produk [9].

\section{METODOLOGI PENELITIAN}

Metode penelitian yang digunakan dalam penelitian ini adalah metode kualitatif dengan pendekatan studi kasus, untuk meneliti secara mendalam dan komprehensif tentang suatu gejala, fakta atau realita [10]. Target populasi dalam penelitian ini adalah seluruh petani jagung dan bawang merah di Lamongan yang menjadi subjek uji coba pasar dari produk baru pupuk mini size AMINA. Petani yang menjadi keseluruhan populasi berjumlah 12 orang, yang mana dipastikan telah memperoleh dan mencoba sampel produk. Metode sampel jenuh diterapkan untuk menjadikan seluruh populasi sebagai subjek penelitian.

Sebelum proses pengumpulan data, daftar penerima sampel produk telah difasilitasi oleh PT Ajinomoto Indonesia. Kemudian dari daftar penerima sampel tersebut dilakukan proses pengumpulang data dengan wawancara kepada 12 petani.

Tahap analisis data dimulai dengan melakukan pengelompokan responden berdasarkan data demografi dan niat adopsinya untuk dihitung presentase responden yang memiliki niat adopsi. Dalam hal ini kode responden digunakan untuk memastikan anonimitas responden. Selanjutnya, pendapat responden mengenai alasan responden mau mengadopsi produk tersebut kemudian dianalisis menggunakan dasar teori Diffusion of Innovations untuk mengetahui faktor-faktor apa yang dapat memengaruhi niat adopsi dari masing-masing responden. Dalam penelitian studi kasus ini analisis dilakukan dengan dua strategi, pertama adalah analisis within-case, kedua adalah analisis across-case. Analisis within-case dilakukan dengan tujuan untuk mengidentifikasi aspek-aspek penting dari setiap kasus berdasarkan pengalaman yang diperoleh masing-masing, sedangkan analisis across-case dilakukan dengan membandingkan beberapa kasus untuk menemukan variasi atau tema tertentu [11]. Selanjutnya, preferensi responden terhadap atribut produk pupuk mini size AMINA juga dianalisis untuk mengetahui preferensi dari mayoritas atau sebagian besar responden. 
Tabel 2.

Skor kepuasan responden

\begin{tabular}{ccccccccc}
\hline \hline $\begin{array}{c}\text { Status tanaman uji } \\
\text { coba }\end{array}$ & \multicolumn{4}{c}{ telah panen } & \multicolumn{3}{c}{$\begin{array}{c}\text { menunggu } \\
\text { panen }\end{array}$} \\
\hline $\begin{array}{c}\text { Skor kepuasan } \\
(1-10)\end{array}$ & 8 & 10 & 8 & 8 & 8 & 9 & 9 \\
$\begin{array}{c}\text { Niat adopsi } \\
\text { responden } \\
\text { Keterangan }\end{array}$ & HT & ST & LA & AF & SH & JR & SN \\
\hline \hline
\end{tabular}

\section{HASIL DAN DISKUSI}

\section{A. Niat Adopsi}

Pernyataan niat adopsi dua belas responden terhadap produk pupuk mini size AMINA ditunjukkan pada tabel 1. Dari tabel 1 menunjukkan bahwa dari dua belas responden terdapat tujuh responden (58\%) yang memiliki niat adopsi terhadap pupuk mini size AMINA, sedangkan lima responden lainnya (42\%) menyatakan belum dapat menentukan niat adopsinya. Hal ini menunjukan bahwa mini size AMINA memiliki tingkat niat adopsi yang cukup besar pada petani jagung dan bawang merah di Lamongan. Terlebih lagi apabila dilihat dari tujuh responden yang telah mampu menilai kualitas produk sehingga dapat menentukan niat adopsinya. Tujuh dari tujuh responden tersebut menyatakan memiliki niat adopsi terhadap pupuk mini size AMINA dengan pernyataan puas hingga sangat puas, seperti dalam tabel 2. Sehingga dari uji coba pasar yang dilakukan menunjukkan bahwa pupuk mini size AMINA memiliki potensi yang besar untuk memasuki pasar petani kecil.

Skor kepuasan pada tabel 2 dinilai berdasarkan tampak fisik tanaman hasil uji coba dan kemudahan penggunaan produk. Tujuh responden merasa puas dengan tampak fisik tanaman hasil uji coba. Namun dari segi kemudahan penggunaan produk terdapat pendapat yang berbeda. ST, JR, dan SN menyatakan produk mudah digunakan yang menjadi sebab pemberian nilai sangat puas (9-10), sedangkan HT, LA, AF, dan SH menyatakan terdapat kesulitan dalam penggunaan produk yang menjadi sebab pemberian nilai puas (7-8).

HT yang merupakan satu-satunya petani perempuan dari tujuh responden yang berniat mengadopsi produk mengalami kesulitan dalam penggunaan produk karena ukuran produk yang terlalu berat.

LA, AF, dan SH mengalami kesulitan penggunaan produk dikarenakan hal yang sama, yaitu mengenai penentuan takaran penggunaan produk. Hal ini dikarenakan produk pupuk mini size AMINA berbeda dengan pupuk yang biasanya digunakan, dimana produk pupuk mini size AMINA berbentuk cair, sednagkan pupuk subsidi berbentuk serbuk atau butiran. Apabila dilihat berdasarkan pengalaman bertaninya, pengalaman bertani LA, AF, dan SH berbeda dengan ST, JR, dan SN. AF adalah petani dengan pengalaman bertani 10 tahun, sedangkan LA dan SH termasuk petani baru dengan pengalaman bertani 4 tahun. ST, JR, dan SN memiliki pengalaman bertani yang sangat lama, yaitu lebih dari 35
Tabel 3.

Kode faktor niat adopsi responden

\begin{tabular}{|c|c|c|c|c|c|}
\hline \multirow{3}{*}{$\begin{array}{c}\text { Kode } \\
\text { responden }\end{array}$} & \multicolumn{5}{|c|}{ Faktor yang memengaruhi niat adopsi terhadap produk } \\
\hline & Relative & & Complex & Observabilit & t Trialabilit \\
\hline & $\mathrm{e}$ & compatibility & $\mathrm{y}$ & $\mathrm{y}$ & $\mathrm{y}$ \\
\hline HT & $\mathrm{x}$ & $\mathrm{x}$ & - & $\mathrm{x}$ & $\mathrm{x}$ \\
\hline ST & $\mathrm{x}$ & $\mathrm{x}$ & $\mathrm{x}$ & $\mathrm{x}$ & $\mathrm{x}$ \\
\hline LA & $\mathrm{x}$ & $\mathrm{x}$ & - & $\mathrm{x}$ & $\mathrm{x}$ \\
\hline $\mathrm{AF}$ & $\mathrm{x}$ & $\mathrm{x}$ & - & $\mathrm{x}$ & $\mathrm{x}$ \\
\hline $\mathrm{SH}$ & $\mathrm{x}$ & $\mathrm{x}$ & - & $\mathrm{x}$ & $\mathrm{x}$ \\
\hline $\mathrm{JR}$ & $\mathrm{x}$ & $\mathrm{x}$ & $\mathrm{x}$ & $\mathrm{x}$ & $\mathrm{x}$ \\
\hline $\mathrm{SN}$ & $\mathrm{x}$ & $\mathrm{x}$ & $\mathrm{x}$ & $\mathrm{x}$ & $\mathrm{x}$ \\
\hline
\end{tabular}

tahun. Dengan demikian didapatkan suatu tema, bahwa pengalaman bertani berperan penting dalam kemudahan penggunaan produk pupuk mini size AMINA. Semakin lama pengalaman bertani dapat mempermudah penggunaan produk, sedangkan pengalaman bertani yang semakin terbatas khususnya bagi petani baru dalam kasus LA dan SH cenderung menimbulkan kesulitan dalam penggunaan pupuk mini size AMINA yang berbeda dengan bentuk pupuk sebelumnya dan pengalaman bertani sebelumnya.

Di samping itu, terdapat beberapa sebab 5 responden belum dapat menentukan niat adopsinya. JN dan KS belum dapat menentukan niat adopsinya karena tanaman yang diuji coba masih berusia 5 minggu dan untuk bisa menentukan niat adopsi terhadap produk pupuk baru perlu melihat hasil panen tanaman yang diuji coba terlebih dahulu. 3 responden lainnya, yaitu MH, AS, SB belum dapat menentukan niat adopsi terhadap pupuk mini size AMINA dikarenakan tanaman yang diuji coba dengan menggunakan pupuk mini size AMINA terkena wabah ulat sehingga tanaman mati dan mengharuskan 3 responden melakukan uji coba ulang.

\section{B. Faktor yang Memengaruhi Niat Adopsi}

Faktor-faktor yang memengaruhi niat adopsi petani jagung dan bawang merah di Lamongan terhadap pupuk mini size AMINA dianalisis menggunakan data 7 responden yang mampu menentukan niat adopsinya, sebagaimana ditunjukkan dalam tabel 3.

1) H1. Relative advantage berpengaruh positif terhadap niat adopsi pupuk mini size AMINA - diterima dalam 7 kasus

Dalam faktor relative advantage, 7 responden menyatakan mau mengadopsi produk pupuk mini size AMINA karena adanya beberapa keunggulan pupuk mini size AMINA dibanding pupuk subsidi yang digunakan sebelumnya, yaitu kualitas produk yang lebih unggul dari pupuk bersubsidi, persepsi pemerolehan produk yang lebih mudah karena dapat dibeli sewaktu-waktu, dan karakteristik pupuk yang lebih mudah diserap tanah.

2) H2. Compatibility berpengaruh positif terhadap niat adopsi pupuk mini size AMINA - diterima dalam 7 kasus

Dalam faktor compatibility, 7 responden menyatakan mau mengadopsi pupuk mini size AMINA karena sesuai dengan apa yang dibutuhkan oleh responden, yaitu kemudahan pemerolehan produk. Hambatan dalam pemerolehan pupuk 
subsidi yang dirasakan oleh tujuh responden ini mendorong adanya kebutuhan produk pupuk yang bisa diperoleh kapan saja. Namun dalam penelitian [12], compatibility tidak hanya dapat dilihat dari kesesuaian produk terhadap kebutuhan responden, melainkan juga dari pengalaman bertani sebelumnya. Dalam hal ini, terdapat temuan ekstrim diluar hipotesis dimana empat responden yaitu HT, LA, AF, dan $\mathrm{SH}$ menyatakan bahwa bentuk produk yang tidak sesuai dengan pengalaman bertani tidak menghalangi niatnya untuk mengadopsi pupuk mini size AMINA, setelah melihat tampak fisik tanaman hasil uji coba. Dengan demikian, bentuk produk mini size AMINA yang kurang sesuai dengan bentuk pupuk subsidi yang selama ini digunakan oleh mayoritas petani bukanlah suatu halangan untuk memasuki pasar apabila produk memiliki kualitas lebih unggul yang terbukti dari hasil uji coba.

3) H3. Complexity berpengaruh negatif terhadap niat adopsi pupuk mini size AMINA - diterima dalam 3 kasus

Hipotesis mengenai complexity seperti yang dinyatakan J. Gamon, N. Harrold, and J. Creswell (1994) dalam Luo, L. Qin et.all (2016) menyatakan bahwa semakin mudah produk inovasi digunakan, maka konsumen potensial akan semakin mau mengadopsi. Sebaliknya, semakin tinggi tingkat kesulitan atau complexity suatu produk baru, maka dapat menghambat niat adopsi konsumen. Selain itu, pada hipotesis penelitian R. Ramanathan, et.all (2016) yaitu semakin kompleks produk dapat menghambat niat adopsi, dapat diterima dalam 3 kasus yaitu ST, JR, dan SN. Produk yang tidak sulit digunakan (kompleksitas rendah) menyebabkan tiga responden memiliki niat untuk mengadopsi produk. Disamping itu, terdapat temuan ekstrim diluar hipotesis yang mana empat responden lainnya yaitu HT, AF, LA, dan SH berpendapat bahwa produk cukup sulit untuk digunakan, namun mereka tetap mau mengadopsi produk. Hal ini berkaitan dengan hasil analisis sebelumnya pada bagian niat adopsi. Dengan demikian, kesulitan penggunaan produk mini size AMINA bagi petani kecil karena memiliki cara penggunaan yang berbeda dari pengalaman bertani sebelumnya bukanlah suatu halangan untuk memasuki pasar apabila produk memiliki kualitas lebih unggul yang terbukti dari hasil uji coba.

4) H4. Observability berpengaruh positif terhadap niat adopsi pupuk mini size AMINA - diterima dalam 7 kasus

Dalam faktor observability, 7 responden menyatakan mau mengadopsi produk pupuk mini size AMINA karena merasa puas dengan hasil fisik tanaman yang dilihat dari hasil uji coba, baik dari tampak fisik tanaman pada masa tanam maupun dari hasil panennya.

5) H5. Trialability berpengaruh positif terhadap niat adopsi pupuk mini size AMINA - diterima dalam 7 kasus Dalam faktor trialability, 7 responden menyatakan mau mengadopsi produk pupuk mini size AMINA karena telah mencoba produk terlebih dahulu, sehingga responden dapat mengetahui kualitas produk dari hasil uji coba yang dilakukan. Hal ini dikarenakan produk mini size AMINA merupakan produk yang benar-benar baru bagi petani kecil, sehingga tanpa mencoba produk, responden cenderung ragu dan enggan untuk mengadopsi produk. Disamping itu, terdapat penemuan menarik diluar hipotesis dari hasil eksplorasi dalam kasus SH, HT, dan JR, bahwa faktor trialability bukanlah faktor yang memengaruhi niat adopsi ketika sudah ada petani lain yang mengadopsi produk baru. Apabila sudah ada petani lain yang menggunakan produk baru, maka petani tidak pasti harus perlu mencoba terlebih dahulu. Dengan melihat dan mendengar mengenai produk tersebut dari petani yang telah mencoba produk, petani dapat menentukan niat adopsi terhadap produk. Hal ini juga menunjukkan bahwa word of mouth masih menjadi media pemasaran yang sangat berpengaruh di dunia pertanian. Petani lebih memercayai word of mouth dari rekan petani. Selain karena hubungan yang sudah terjalin dengan baik dan adanya kepercayaan antarpetani, hasil dari penggunaan produk baru yang digunakan petani lain juga dapat dibuktikan secara nyata. Dari temuan tersebut menunjukkan bahwa trialability penting dalam memengaruhi niat adopsi dari pengadopsi pertama produk pupuk mini size AMINA, sedangkan bagi pengadopsi selanjutnya trialability belum tentu merupakan faktor yang penting. Telah dijelaskan oleh gagasan teori E. M. Rogers (2003) dalam penelitian L.Warner, at. all (2019), bahwa pengadopsi pertama dalam Diffusion of Innovation Theory disebut sebagai innovators, sedangkan pengadopsi produk inovasi pada periode setelah innovators disebut early adopter. Hal ini menarik untuk dijadikan rekomendasi penelitian selanjutnya.

\section{Preferensi Konsumen}

Preferensi konsumen terhadap atribut produk dianalisis dengan data dari dua belas responden, kecuali untuk atribut harga. Atribut harga dianalisis hanya dari data 7 responden yang menyatakan telah dapat menilai kualitas produk dan mampu menentukan niat adopsi, sehingga responden dapat menentukan berapa harga yang sesuai dengan kualitas produk yang dipersepsikan.

Preferensi atribut harga dengan nilai terendah adalah Rp5.000 yang dinyatakan oleh dua responden yaitu HT dan SH, sedangkan nilai tertinggi adalah Rp10.000 yang hanya dinyatakan oleh satu responden yaitu LA. Namun mayoritas responden yaitu empat petani memberi harga Rp6.000 untuk produk mini size AMINA. Pemberian harga Rp5.000 oleh HT dan SH yang lebih rendah dari penilaian kebanyakan responden disebabkan oleh perekonomian individu yang bisa dibilang lemah. Dengan demikian, harga satu jirigen pupuk mini size AMINA yang dipersepsikan oleh petani kecil subjek uji coba sesuai dengan kualitas produk namun juga dapat dijangkau oleh target pasar adalah antara Rp5.000 hingga Rp6.000. Rentang harga tersebut dimaksudkan agar dapat dijangkau oleh petani kecil yang cenderung memiliki perekonomian lemah T. Mardikanto (1990) dan sensitif terhadap harga H. Channa, et. all (2019), sehingga produk baru pupuk mini size AMINA dapat menjangkau target pasar yang lebih luas.

Pada preferensi atribut volume diperoleh bahwa responden yang merupakan petani laki memilih volume 20 liter karena tidak terlalu kecil dan tidak terlalu besar. Hal ini 
Tabel 4.

Nilai constant ratio untuk berbagai kombinasi pasangan

\begin{tabular}{|c|c|c|c|c|}
\hline $\begin{array}{c}\text { Kode } \\
\text { Responden }\end{array}$ & HT & ST & LA & $\mathrm{AF}$ \\
\hline $\begin{array}{c}\text { Jenis } \\
\text { Kelamin }\end{array}$ & Perempuan & Laki laki & Laki laki & Laki laki \\
\hline Usia & 57 tahun & 61 tahun & 32 tahun & 30 tahun \\
\hline $\begin{array}{c}\text { Pendidikan } \\
\text { terakhir }\end{array}$ & SD & SD & SLTA & SLTA \\
\hline $\begin{array}{l}\text { Pendapatan } \\
\text { rata rata } \\
\text { perbulan }\end{array}$ & $\begin{array}{c}\text { Rp1.100.000 } \\
-2.000 .000\end{array}$ & $\begin{array}{c}\text { Rp2.100.000 } \\
-3.000 .000\end{array}$ & $\begin{array}{c}\text { Rp2.100.000 } \\
-3.000 .000\end{array}$ & $\begin{array}{c}\text { Rp2.100.000 } \\
-3.000 .000\end{array}$ \\
\hline $\begin{array}{c}\text { Lama } \\
\text { bertani }\end{array}$ & 42 tahun & 49 tahun & 4 tahun & 10 tahun \\
\hline $\begin{array}{c}\text { Luas lahan } \\
\text { total } \\
\text { Status }\end{array}$ & 0,15 ha & 0,25 ha & 0,15 ha & 0,2 ha \\
\hline $\begin{array}{l}\text { kepemilikan } \\
\text { lahan }\end{array}$ & pribadi & Sewa & Pribadi & pribadi \\
\hline $\begin{array}{c}\text { Jenis } \\
\text { tanaman }\end{array}$ & jagung & Jagung & $\begin{array}{c}\text { bawang } \\
\text { merah }\end{array}$ & $\begin{array}{c}\text { bawang } \\
\text { merah }\end{array}$ \\
\hline $\begin{array}{c}\text { Usia } \\
\text { tanaman uji } \\
\text { coba }\end{array}$ & $\begin{array}{l}15 \text { minggu } \\
\text { (sudah } \\
\text { panen) }\end{array}$ & $\begin{array}{l}15 \text { minggu } \\
\text { (sudah } \\
\text { panen) }\end{array}$ & $\begin{array}{l}9 \text { minggu } \\
\text { (sudah } \\
\text { panen) }\end{array}$ & $\begin{array}{l}9 \text { minggu } \\
\text { (sudah } \\
\text { panen) }\end{array}$ \\
\hline
\end{tabular}

Tabel 5 .

Nilai constant ratio untuk berbagai kombinasi pasangan

\begin{tabular}{|c|c|c|c|c|}
\hline $\begin{array}{c}\text { Kode } \\
\text { Responden }\end{array}$ & $\mathrm{SH}$ & JR & SN & $\mathrm{JN}$ \\
\hline $\begin{array}{c}\text { Jenis } \\
\text { Kelamin }\end{array}$ & Laki laki & Laki laki & Laki laki & Laki laki \\
\hline Usia & 40 tahun & 51 tahun & 64 tahun & 47 tahun \\
\hline $\begin{array}{c}\text { Pendidikan } \\
\text { terakhir }\end{array}$ & SMP & SD & SD & SD \\
\hline $\begin{array}{l}\text { Pendapatan } \\
\text { rata rata } \\
\text { perbulan }\end{array}$ & $\begin{array}{c}\text { Rp1.100.000 } \\
-2.000 .000\end{array}$ & $\begin{array}{c}\text { Rp2.100.000 } \\
-3.000 .000\end{array}$ & $\begin{array}{l}\text { Rp1.100.000 } \\
-2.000 .000\end{array}$ & $\begin{array}{l}\text { Rp2.100.000 } \\
-3.000 .000\end{array}$ \\
\hline $\begin{array}{c}\text { Lama } \\
\text { bertani }\end{array}$ & 4 tahun & 40 tahun & 55 tahun & 30 tahun \\
\hline $\begin{array}{l}\text { Luas lahan } \\
\text { total }\end{array}$ & 0,15 ha & 0,2 hektar & 0,25 ha & 0,25 ha \\
\hline $\begin{array}{c}\text { Status } \\
\text { kepemilikan } \\
\text { lahan }\end{array}$ & pribadi & Sewa & Sewa & pribadi \\
\hline $\begin{array}{c}\text { Jenis } \\
\text { Kelamin }\end{array}$ & Laki laki & Laki laki & Laki laki & Laki laki \\
\hline Usia & 40 tahun & 51 tahun & 64 tahun & 47 tahun \\
\hline
\end{tabular}

dikarenakan ukuran produk yang terlalu kecil dapat membuat proses pemupukan lebih lama dan sulit untuk dibawa apabila petani membeli dalam jumlah yang banyak sekaligus, sedangkan ukuran produk yang terlalu besar juga dapat menyulitkan petani ketika membawa produk karena semakin berat. Namun, responden yang merupakan petani perempuan (HT dan KS) lebih memilih volume 15 liter, karena produk dengan volume 20 liter masih terlalu berat untuk dipikul bagi petani perempuan. Perbedaan preferensi ini menjadi penting untuk dipertimbangkan, mengingat petani perempuan juga merupakan konsumen potensial.

Pada preferensi label sertifikasi kualitas, sebagian besar petani cenderung tidak menganggap penting adanya label sertifikasi pada produk. Terutama bagi petani yang sudah berusia lansia, yang berasal dari generasi $\mathrm{X}$ maupun $\mathrm{Y}$. Namun, yang menarik dari hasil penelitian, terdapat 4 petani yang menyatakan perlunya tanda sertifikasi produk yaitu responden LA, AF, SH, dan SB. Keempat responden ini memiliki latar belakang pendidikan yang lebih tinggi dari responden lainnya. Hal ini menunjukkan bahwa semakin tinggi pendidikan yang dimiliki petani, maka dapat memengaruhi pola berpikir dan semakin kritis ketika menentukan suatu hal. Pendidikan yang semakin tinggi membuat petani semakin memerhatikan hal hal seperti kandungan zat dan sertifikasi produk dalam memilih produk pertanian seperti pupuk. Nilai constant ratio untuk berbagai kombinasi pasangan dapat dilihat pada Table 4 sampai Tabel 5. Pada preferensi jarak tempat pembelian, mayoritas responden (9 dari 12 responden) memilih jarak antara 2-3 kilometer. Hal ini menunjukkan bahwa tempat pembelian yang diinginkan oleh responden berjarak dekat dari lahan bertaninya. Hal ini wajar adanya karena responden sebelumnya merupakan konsumen dari pupuk subsidi yang mana untuk memperolehnya tidak memerlukan jarak yang jauh.

\section{Implementasi Manajerial}

Produk baru pupuk mini size AMINA saat ini berada pada tahap pengembangan produk yang dalam waktu dekat akan diluncurkan ke pasar, sehingga implikasi manajerial dalam hal ini meliputi strategi yang dapat dilakukan pada tahap pengembangan produk dan tahap perkenalan produk. Melihat potensi mini size AMINA yang besar untuk memasuki pasar, maka perusahaan perlu mempersiapkan berbagai hal terkait pengembangan produk hingga produk layak untuk dipasarkan, kemudian melakukan strategi pemasaran yang tepat dan efektif untuk memperkenalkan produk baru tersebut kepada konsumen.

Saat melakukan komersialisasi produk penting untuk menjaga kualitas produk, sebab kualitas produk dan hasil tanaman uji coba menjadi pendorong petani jagung dan bawang merah dalam penelitian ini untuk berniat mengadopsi produk. Bahkan dalam beberapa kasus ekstrim, kesulitan dalam penggunaan produk (complexity) tidak menghambat petani untuk berniat mengadopsi produk setelah melihat hasil tanaman yang memuaskan. Hal ini menunjukkan bahwa kualitas produk bisa menjadi kekuatan produk untuk memasuki pasar yang baru.

Pupuk mini size AMINA merupakan produk yang benarbenar baru bagi petani, sehingga petani perlu mencoba produk terlebih dahulu. Pentingnya faktor trialability dapat memberi pandangan bahwa pada tahap awal perkenalan produk setelah launching produk dilakukan, perusahaan dapat melakukan sales promotion dengan memberi sampel produk gratis untuk dicoba petani yang ada di beberapa daerah target pasar dan melakukan demonstration plot dengan meminjam atau menyewa lahan dari petani di suatu daerah untuk dijadikan lahan uji coba. Melalui demonstration plot perusahaan dapat memberikan sosialisasi secara langsung kepada para petani disertai praktik penggunaan produk. Hasil tanaman yang dicoba pada lahan demplot ini nantinya juga dapat dilihat oleh petani sekitar, sehingga strategi advertising juga dapat diterapkan dengan memasang spanduk pada lahan yang sedang di uji coba pada masyarakat luas. Dengan strategi pemasangan spanduk dapat memunculkan rasa perhatian petani sekitar 
Tabel 6.

Nilai constant ratio untuk berbagai kombinasi pasangan

\begin{tabular}{|c|c|c|c|c|}
\hline $\begin{array}{c}\text { Jenis } \\
\text { tanaman }\end{array}$ & jagung & Jagung & Jagung & jagung \\
\hline $\begin{array}{c}\text { Usia } \\
\text { tanaman uji } \\
\text { coba }\end{array}$ & $\begin{array}{l}15 \text { minggu } \\
\text { (sudah } \\
\text { panen) }\end{array}$ & 5 minggu & 5 minggu & 5 minggu \\
\hline $\begin{array}{c}\text { Kode } \\
\text { Responden }\end{array}$ & KS & MH & AS & SB \\
\hline $\begin{array}{c}\text { Jenis } \\
\text { Kelamin }\end{array}$ & Perempuan & Laki laki & Laki laki & Laki laki \\
\hline Usia & 50 tahun & 68 tahun & 72 tahun & 63 tahun \\
\hline $\begin{array}{l}\text { Pendidikan } \\
\text { terakhir }\end{array}$ & SD & SD & SD & SLTA \\
\hline $\begin{array}{l}\text { Pendapatan } \\
\text { rata rata } \\
\text { perbulan }\end{array}$ & $\begin{array}{c}\text { Rp1.100.000 } \\
-2.000 .000\end{array}$ & $\begin{array}{l}\text { Rp1.100.000 } \\
-2.000 .000\end{array}$ & $\begin{array}{l}\text { Rp1.100.000 } \\
-2.000 .000\end{array}$ & $\begin{array}{l}\text { Rp1.100.000 } \\
-2.000 .000\end{array}$ \\
\hline $\begin{array}{c}\text { Lama } \\
\text { bertani }\end{array}$ & 20 tahun & 2 tahun & 57 tahun & 33 tahun \\
\hline $\begin{array}{l}\text { Luas lahan } \\
\text { total }\end{array}$ & 0,25 ha & 0,25 ha & 0,2 ha & 0,35 ha \\
\hline $\begin{array}{l}\text { Luas lahan } \\
\text { diuji coba } \\
\text { Status }\end{array}$ & 0,2 ha & 0,25 ha & 0,2 ha & 0,35 ha \\
\hline $\begin{array}{l}\text { kepemilikan } \\
\text { lahan }\end{array}$ & Sewa & Pribadi & Pribadi & Pribadi \\
\hline $\begin{array}{l}\text { Jenis } \\
\text { tanaman } \\
\text { Usia }\end{array}$ & Jagung & Jagung & Jagung & Jagung \\
\hline $\begin{array}{c}\text { tanaman uji } \\
\text { coba }\end{array}$ & 5 minggu & - & - & - \\
\hline
\end{tabular}

terhadap produk.

Disamping itu, perusahaan perlu membuat panduan berisi takaran penggunaan produk untuk berbagai jenis tanaman dan pendampingan personal kepada penerima sampel penting dilakukan. Kurangnya pengalaman bertani khususnya bagi petani muda cenderung membuat petani merasa kesulitan menggunakan pupuk cair AMINA yang memiliki cara penggunaan berbeda, terlebih lagi jika petani muda tersebut belum pernah menggunakan pupuk berbentuk cair sebelumnya. Dengan demikian, dalam uji coba diperlukan adanya informasi jelas mengenai cara penggunaan pupuk mini size AMINA terutama mengenai takaran penggunaan pupuk pada tanaman tertentu yang akan digunakan sebagai uji coba. Oleh karena itu, perusahaan dapat memberi penyuluhan kepada penerima sampel produk sebelum menggunakannya dan kemudian melakukan pendampingan ketika penggunaan produk untuk menimalisir risiko kegagalan uji coba.

Pengadaan penyuluhan atau sosialisasi dapat bekerjasama dengan gapoktan (gabungan kelompok tani) maupun pada skala yang lebih kecil, yaitu kelompok tani. Bekerjasama dengan gapoktan dapat dilakukan untuk memperkenalkan produk mini size AMINA melalui pengadaan kegiatan yang bermanfaat bagi petani kecil, seperti pelatihan dan konsultasi pertanian. Perusahaan dapat mengadakan pertemuan dengan gapoktan atau kelompok tani untuk pengenalan perusahaan, edukasi, dan penyuluhan.

Mengingat bahwa ketersediaan produk pupuk yang dapat dibeli sewaktu-waktu merupakan kebutuhan petani kecil, maka perusahaan perlu menjaga kontinuitas ketersediaan produk di pasar. Terlebih lagi produk mini size AMINA merupakan produk hasil samping industri yang mana produksinya bergantung dari hasil samping produksi dengan kuantitas tertentu setiap harinya. Hal ini menjadi tantangan perusahaan, karena perusahaan harus siap dan mampu memenuhi permintaan pasar nantinya. Apabila dilihat dari keseluruhan responden, petani yang memiliki niat adopsi terhadap produk baru mini size AMINA berasal dari berbagai generasi, baik generasi baby bloomer, X, dan milenial. Dengan demikian, produk memiliki peluang untuk menyasar petani dari berbagai generasi, sehingga strategi pemasaran yang dilakukan juga harus menyesuaikan karakter dari setiap generasi yang menjadi target konsumen. Pemasaran tradisional yang dapat dilakukan untuk menyasar petani generasi tua, diantaranya adalah dengan memberikan pamflet atau brosur penawaran yang berisi informasi produk secara lengkap, sedangkan untuk menyasar petani milenial dapat dilakukan pemasaran secara online dengan membuat website yang di dalamnya terdapat informasi lengkap mengenai produk, tata cara penggunaan produk yang lebih atraktif, panduan dosis setiap tanaman.

Selain itu, adanya perbedaan preferensi dapat dipertimbangkan kembali oleh perusahaan untuk menyusun produk yang benar-benar akan dikomersialisasi, sehingga produk dapat sesuai dengan keinginan konsumen dan dapat lebih mudah diterima oleh target pasar.

\section{SIMPULAN DAN SARAN}

Dari hasil analisis disimpulkan bahwa 7 dari 12 responden (58\%) menyatakan memiliki niat adopsi produk mini size AMINA dengan nilai kepuasan 8 hingga 10 (puas hingga sangat puas) berdasarkan penilaian dari tampak fisik hasil tanaman hasil uji coba dan kemudahan penggunaan produk. 5 responden lainnya (42\%) menyatakan belum dapat menentukan niat adopsinya, yang mana 2 responden belum dapat menilai tampak fisik hasil tanaman uji coba yang masih dalam masa tanam, sedangkan 3 responden harus melakukan uji coba ulang karena tanamannya terserang wabah ulat. Dengan demikian, tingkat niat adopsi dari petani jagung dan bawang merah terhadap mini size AMINA cukup besar. Terlebih lagi jika dilihat dari pernyataan tujuh responden yang sudah dapat menentukan niat adopsinya. Tujuh dari tujuh responden tersebut menyatakan mau mengadopsi produk baru pupuk mini size AMINA dengan pernyataan puas.

Terdapat 5 faktor yang dapat memengaruhi petani jagung dan bawang merah untuk berniat mengadopsi produk baru pupuk mini size AMINA, yaitu relative advantage, compatibility, complexity, observability, dan trialability. Relative advantage memengaruhi niat adopsi dari 7 responden karena kualitas produk yang lebih unggul, persepsi pemerolehan yang lebih mudah, dan karakteristik pupuk yang lebih mudah diserap tanah. Compatibility memengaruhi niat adopsi dari 7 responden karena sesuai dengan kebutuhan responden terhadap produk pupuk, yaitu yang mudah diperoleh dan selalu tersedia. Complexity memengaruhi niat adopsi dari 3 responden dikarenakan penggunaan produk yang mudah (tidak kompleks). Observability memengaruhi niat 
adopsi dari 7 responden karena hasil penerapan uji coba dapat terlihat secara nyata dari tampak fisik tanaman maupun hasil panen. Trialability memengaruhi niat adopsi dari tujuh responden yang mana dengan melakukan uji coba dapat menimbulkan niat adopsi, karena pupuk mini size AMINA merupakan produk baru sehingga untuk menentukan niat adopsi harus mencoba terlebih dahulu.

Mengenai preferensi konsumen, preferensi sebagian besar responden terkait atribut produk mini size AMINA antara lain adalah harga dengan rentang Rp5.000-Rp6.000, volume 20 liter, tidak memiliki keterangan sertifikasi produk, dan tempat pembelian berjarak antara 2-3 kilometer dari lahan bertani.

Disamping itu, terdapat beberapa rekomendasi penelitian selanjutnya, antara lain penelitian pada petani kecil dari berbagai wilayah sehingga diperoleh cakupan yang lebih luas, penelitian eksplanatori untuk mengetahui signifikansi faktor yang memengaruhi niat adopsi petani kecil, penelitian eksplanatori untuk mengidentifikasi signifikansi faktor-faktor yang memengaruhi niat adopsi dari setiap kategori pengadopsi, baik innovators, early adopter, maupun pengadopsi selanjutnya, dan penelitian mengenai pengaruh karakter individu terhadap niat adopsi produk inovasi pertanian secara luas. Selain itu strategi branding dari produk baru juga menarik untuk dijadikan topik penelitian selanjutnya, melihat ada beberapa kompetitor dalam produk yang serupa dan berpotensi untuk menjadi pesaing pupuk cair hasil samping industri berukuran kecil.

\section{DAFTAR PUSTAKA}

[1] Badan Pusat Statistik, "Pertumbuhan Ekonomi Indonesia Triwulan IV2019,"Www.Bps.Go.Id, no. 17/02/Th. XXIV, pp. 1-12, 2020, [Online].
Available:https://www.bps.go.id/pressrelease/2020/02/05/1755/ekonomi -indonesia-2019-tumbuh-5-02-persen.html.

[2] Subdirektorat Statistik Ekspor, "Analisis Komoditas Ekspor 2012-2018 Sektor Pertanian, Industri, dan Pertambangan," CV. Kemsiro Berkarya, 2018. [Online]. Available: https://www.bps.go.id/pressrelease/2020/02/05/1755/ekonomiindonesia-2019-tumbuh-5-02-persen.html.

[3] APPI, "Konsumsi Pupuk Domestik 2015-2018," 2019. [Online]. Available: www.appi.or.id.

[4] S. H. Susilowati, "Alternatif Penyempurnaan Kebijakan Subsidi Pupuk," Ragam Pemikiran Menjawab Isu Aktual Pertanian, pp. 47-78, 2018.

[5] J. Tur-Cardona et al., "Farmers' reasons to accept bio-based fertilizers: A choice experiment in seven different European countries," J. Clean. Prod., vol. 197, pp. 406-416, 2018, doi: 10.1016/j.jclepro.2018.06.172.

[6] S. Tih, K.-K. Wong, G. Lynn, and R. R. Relly, "Prototyping, Customer Involvement, and Speed of Information Dissemination in New Product Success," J. Bus. Ind. Mark., vol. 16, no. July 2001, pp. 294-308, 2019, doi: 10.1108/EUM0000000005502.

[7] L. Warner, C. Silvert, and M. Benge, "Using Adoption and Perceived Characteristics of Fertilizer Innovations to Identify Extension Educational Needs of Florida's Residential Audiences.," J. Agric. Educ., vol. 60, no. 3, pp. 155-172, 2019, doi: 10.5032/jae.2019.03155.

[8] K. K. Kapoor, Y. K. Dwivedi, and M. D. Williams, "Rogers' Innovation Adoption Attributes: A Systematic Review and Synthesis of Existing Research,” Inf. Syst. Manag., vol. 31, no. 1, pp. 74-91, 2014, doi: 10.1080/10580530.2014.854103.

[9] M. Voicu, "Characteristics of the Consumer Preferences Research Process," Glob. Econ. Obs., vol. 1, no. 1, pp. 126-134, 2013.

[10] R. K. Yin, Case Study Research: Design and Methods. Thousand Oaks, California: SAGE Publication, Inc., 2009.

[11] L. Ayres, K. Kavanaugh, and K. A. Knafl, "Within-Case and AcrossCase Approaches to Qualitative Data Analysis," Qual. Health Res., vol. 13, no. 6, pp. 871-883, 2003, doi: 10.1177/1049732303255359.

[12] L. Luo, L. Qin, Y. Wang, and Q. Wang, "Environmentally-friendly agricultural practices and their acceptance by smallholder farmers in China-A case study in Xinxiang County, Henan Province," Sci. Total Environ., vol. 571, pp. 737-743, 2016, doi: 10.1016/j.scitotenv.2016.07.045. 